\title{
THE OMAHU AFFAIR, THE LAW OF SUCCESSION AND THE NATIVE LAND COURT
}

\author{
RP Boast QC ${ }^{*}$
}

\begin{abstract}
This article discusses the Omahu affair, a prominent legal drama that took place in the late 19th century involving prominent Màori leaders from the Hawke's Bay region. The case was the subject of numerous Native Land Court hearings, decisions of the ordinary courts, and ultimately a Privy Council decision in London. This article considers how tensions within the Māori community could drive cases in the Native Land Court, and explores the interconnections between that Court and the ordinary courts. It seeks to promote a more sophisticated view of the Court's role, particularly in the context of inter-Māori disputes, as well as of the complexities of legal and political affairs in 19th century New Zealand. The article also raises some questions relating to the role of elites in the Māori community, and the interconnections between Māori and European elites in 19th century New Zealand.
\end{abstract}

\section{INTRODUCTION: A FORGOTTEN LEGAL DRAMA}

This article is about a sensational legal drama which is now forgotten - except, that is, by the descendants of those involved in it. In its day, however, the intertwined affair of the Omahu block and the Māori chief Renata Kawepo's will was a legal saga that generated an enormous amount of public interest, especially in Hawke's Bay, where it can fairly be said to have engrossed the attention of practically everyone in the province. Nationally prominent lawyers were involved in the matter, notably Sir Robert Stout, later to be Chief Justice, and William L Rees, who had a very large Native Land Court practice, and who was closely connected with a number of leading Māori politicians and community leaders, and who was himself a Liberal politician. The dispute tore the Māori

* Professor, Faculty of Law, Victoria University of Wellington. Research for this article derived from a project on land tenure on the Pacific Rim supported by the Marsden Fund, administered by the Royal Society of New Zealand. Many thanks to Ryan O'Leary for assistance with the research. May I also thank the editors of this festschrift for Professor Atkin for inviting me to contribute to this collection. I would like to pay tribute to Professor Atkin for his many contributions to teaching and scholarship at this Law Faculty. I hope he finds this article to be an interesting sidelight on the complexities of the history of the law of succession in New Zealand. 
community of Hawke's Bay apart and resulted in the violent death of a well-respected young Māori aristocrat in June 1889. The affair generated numerous cases in the Native Land Court and resulted ultimately in a decision of the Judicial Committee of the Privy Council. ${ }^{1}$

The Native Land Court is usually written about by historians as part of the history of Māori land alienation, and has been repeatedly stereotyped as an agency of dispossession. Some historians see the Court as essentially a tool of the Crown; others accuse its judges, particularly its first Chief Judge (Francis Dart Fenton) of pursuing their own agendas and of wilfully ignoring directions from Parliament. ${ }^{2}$ I do not intend to assess these judgments of the Native Land Court here, and in any event it is much more important, in my view, to set the Native Land Court and its statutory underpinnings in a wider comparative and historical context. This article's focus is on how tensions within the Māori community could drive cases in the Court, and on the interconnections between the Native Land Court and the ordinary courts. The Court could at times also reflect national political alignments and debates in what was a deeply politicised society, and one in which Māori were often at odds with each other.

One aspiration of this article is to escape from an increasingly outmoded, and by now tedious, vision of 19th century New Zealand legal history, which tends to interpret that history in terms of a contest between "Māori" and "the Crown", and in which the central point at issue is whether or not the Crown can be said to be in breach of the Treaty of Waitangi. "The Crown", more precisely the government of the day, was not directly involved in the Omahu case, which had nothing whatever to do with the Treaty of Waitangi or the common law of native title. It was an inter-Māori dispute, albeit one which absorbed the attention of the whole community, Māori and Pākehā alike, and was fought out within the framework of the ordinary law relating to probate of wills and the statutes relating to Māori land and the Native Land Court. Yet it was an extremely serious and tragic affair, and it certainly deserves to be better known. I hope to convey something of the complexities of political and legal affairs in 19th century New Zealand, and for this reason the narrative will cite extensively from primary sources, especially from newspapers. ${ }^{3}$

1 Donnelly v Broughton [1891] AC 435 (PC).

2 David V Williams has argued that the relationship between the Native Land Court and the Government was so close as to be a breach of the doctrine of the separation of powers: see David V Williams Te Kooti Tango Whenua: The Native Land Court 1864-1909 (Huia Publishers, Wellington, 1999) at 44. On the other hand, Alan Ward has seen the Court's first Chief Judge (FD Fenton) as being far too independent and prone to ignoring the directions of Parliament: see Alan Ward A Show of Justice: Racial "amalgamation" in nineteenth century New Zealand (Auckland University Press, Auckland, 1995) at 213. See also RP Boast The Native Court 1862-1887: A Historical Study, Cases and Commentary (Thomson Reuters, Wellington, 2013) at 189-195.

3 Along with many other researchers, I am indebted to the organisers of the Papers Past website, which makes available a vast amount of newspaper material available in a searchable format. This article could not have been written without this resource. See Papers Past <www.paperspast.natlib.govt.nz>. 
The judgments of the Native Land Court relating to the Omahu block at first instance and at the rehearing of the case have only recently been edited and published. ${ }^{4}$ For reasons I have not been able to discover, decisions of the Native Land Court and its various supplementary and appellate bodies (such as the Compensation Court, the Validation Court, the Urewera Commission and the Native Appellate Court $)^{5}$ were never deemed worthy of inclusion in the New Zealand Law Reports or in the less durable Gazette Law Reports. Yet these cases often involved very substantial and valuable blocks of land and many of the judgments released by the Court were lengthy, carefully

4 RP Boast (ed) The Native Land Court Volume 2, 1887-1909: A Historical Study, Cases, and Commentary (Thomson Reuters, Wellington, 2015). This is a sequel to my Native Land Court 1862-1887, above n 2. Volume 2 contains complete and fully edited texts of the Omahu decision of 1890 ((1890) 20 Napier MB at 131-134), the Kawera decision of 1890 ((1890) 20 Napier MB at 337) and the Omahu rehearing decision of 1892 ((1892) 26 Napier MB at 7-8). These decisions can be found in vol 2 indexed respectively as NLC 158 [Omahu investigation] (at 492-506), NLC 160 [Kawera] (at 510-513) and NLC 181 [Omahu rehearing] (at 692-702). Citations in this article will give both the original pagination in the Court minute book (MB) and in my 2015 edition of Land Court judgments. As explained in the text, decisions of the Native Land Court were not reported in the New Zealand Law Reports or in the Gazette Law Reports. Instead they were written out, or pasted into, the Court minute books. The minute books are organised by region; thus there are, for instance, the Napier, Whanganui, Wellington, Otaki, Taranaki, Taupō, Rotorua and other sequences of minute books, which run from the first sittings of the Land Court in that place or district down to the present time. Often the judgments are written out in longhand, but judgments were occasionally printed as pamphlets or published in local newspapers. Newspaper texts were pasted by the court clerk into the appropriate folium of the minute book. The three decisions relating to Omahu were all printed in the local newspaper (the Hawke's Bay Herald) and were also pasted into the appropriate volumes of the Napier minute books, which also give a verbatim account of the evidence and cross-examination written out in longhand. Hard copies of the Napier minute books can be found at National Archives in Wellington and at the Maori Land Court Registry in Hastings, and can be freely consulted by members of the public.

5 The Compensation Court, which was staffed by some of the judges of the Native Land Court, was set up to deal with land confiscated under the New Zealand Settlements Act 1863 and its amendments. Its principal decisions were made in 1866-1867. (On this Court, and its case law, see Boast, above n 2, at 29-43; and RP Boast "An Expensive Mistake: Law, Courts, and Confiscation on the New Zealand Colonial Frontier" in Richard Boast and Richard Hill (eds) Raupatu: The Confiscation of Maori Land (Victoria University Press, Wellington, 2009) 145.) The Validation Court was set up by the Native Land (Validation of Titles) Act 1893, and was a specialist court, staffed by some of the Native Land Court judges, with a jurisdiction to "validate" purchases and leases of Māori land which for various reasons had failed to comply with the requirements of the Native Lands Acts. The Validation Court - its functions rendered largely irrelevant by the Privy Council in Assets Co Ltd v Mere Roihi [1905] AC 176 (PC) - was abolished by the Native Land Act 1909 and its functions transferred to the Native Land Court. (On the Validation Court, see Boast, above n 4, at 143-168.) The Urewera Commission was set up by the Urewera District Native Reserve Act 1896 and investigated titles to land within the Urewera District Native Reserve (principally affecting the Tūhoe people, but also affecting Ngāti Whare, Ngāti Manawa, Ngāti Hingaanga and some other groups). It was by replaced by the Native Land Court acting under its ordinary jurisdiction by s 5 of the Urewera District Native Reserve Amendment Act 1909. The Native Appellate Court was established by s 79 of the Native Land Court Act 1894 (prior to this time all appeals from the Native Land Court were by way of full rehearings). (On the Urewera Commission, see Boast, above n 4, at 221-247; and on the establishment of the Appellate Court, at 35-37.) The Native Appellate Court, as the Māori Appellate Court, still exists and hears appeals from the Māori Land Court. 
reasoned and no less detailed and comprehensive than many decisions of the Supreme Court and the Court of Appeal. Far from being of interest only to the parties, many cases in the Native Land Court were regarded at the time as being of pivotal importance to both the Māori and Pākehā communities in such regions as the Waikato, Gisborne and Hawke's Bay. The major cases were closely followed in the newspapers, which often published the Court's judgments in full. The Omahu cases are an example. Here the evidence was reported in detail in the local newspapers and many national ones, all the judgments given (some of them quite lengthy) were published, and the matter generated a great deal of concern and controversy. While the judgments relating to Renata Kawepo's will given by the Supreme Court, the Court of Appeal and in the Privy Council - being decisions of the ordinary courts - were all reported, the Omahu decisions of the Native Land Court and Native Appellate Court have not been. Yet the full history of the affair cannot be comprehended without taking all of the relevant decisions into account.

\section{SUCCESSION TO INTERESTS IN MĀORI FREEHOLD LAND}

At the heart of the Omahu affair was a contested will. It thus becomes necessary to deal with the issue of jurisdiction over succession. We are concerned here both with the ordinary courts of New Zealand, and with the Native Land Court, a specialist tribunal set up by the Native Lands Acts of 1862 and 1865 to investigate titles to Māori land blocks and to issue titles to the Māori owners. New Zealand's Māori land legislation has a number of affinities with other remodellings of customary tenures created by statute in various jurisdictions around the Pacific Rim at roughly the same time, and which derive in their turn from various strands of liberal ideology current in Europe. ${ }^{7}$ The

6 Although there is a very substantial literature on the Native Land Court and the Native Lands Acts, there is not a large literature on the legal history of the law relating to successions to Māori land interests. The principal treatment is Tom Bennion and Judi Boyd Rangahaua Whanui National Theme P: Succession to Maori Land, 1900-1952 (Waitangi Tribunal, May 1997).

7 Analysing and comparing these enactments, and tracing their common ideological foundations, is the principal purpose of the research project referred to above. (For a preliminary review of some of the findings of this research project, see RP Boast "The Ideology of Tenurial Revolution: The Pacific Rim 1850-1950" (2014) 1 law\&hist 137.) One important component of the liberal brew was a belief in the social and economic benefits of individual - rather than corporate, or collective - ownership of land. This basic idea underpins land reform statutes across the world in the 19th century, including Prussia's Allgemeines Landsrecht (1807), the various General Enclosure Acts in the United Kingdom, the Ley Madoz in Spain, Mexico's Ley Lerdo (1856), the Ottoman Land Act of 1858, and New Zealand's Native Lands Acts of 1862 and 1865. Parliamentary enclosure in Britain rests on essentially the same ideological foundations, which in turn had classical antecedents: see SJ Thompson "Parliamentary Enclosure, Property, Population, and the Decline of Classical Republicanism in Eighteenth-Century Britain" (2008) 51 The Historical Journal 621. Individualisation "was an article of faith of the liberals of the $19^{\text {th }}$ century: individual property rights in real property would provide the stimulus for national economic progress; consequently it was necessary to put an end to both ecclesiastical and civil corporate ownership": RJ Knowlton "La división de las tierras de los pueblos durante el siglo XIX: el caso de Michoacán" (1990) 40 Historia Mexicana 3 at 4 (my translation). For helpful collections of essays on liberalism and tenurial change in Spain and Latin America see Robert $\mathrm{H}$ Jackson (ed) Liberals, the Church, and Indian Peasants (University of New Mexico Press, Albuquerque, 1997); Erika Pani (ed) Nación, Constitución y Reforma, 1821-1908 (Fondo de Cultura Económica, México 
principal type of case that the Native Land Court heard was called an investigation of title. ${ }^{8}$ (The Omahu cases discussed in this article were investigations of title, or rehearings of them.) Such a case was concerned with the title to a surveyed block of land, which could be anything from a few hundred acres in extent to tens or even hundreds of thousands of acres, and with the two biggest cases (King Country - or Rohe Potae - and Tauponuiatia, both heard in 1886), over a million. ${ }^{9}$ Hearings were presided over by a judge of the Native Land Court, few of whom were qualified lawyers, assisted by a Māori assessor. Decisions were required to be unanimous. ${ }^{10}$ The "investigation" was essentially an inquiry into the customary ownership of the block, and the parties were entirely Māori. The Crown played no role in the Native Land Court for the most part. ${ }^{11}$

The Court was a peripatetic one, and cases were heard at many venues all over the country, the judges having to make do with whatever venues could be found - these ranging from country stores to town halls to waiting rooms at a hospital, or, more usually, magistrates' courtrooms in provincial towns. Cases were normally contested, with numerous groups claiming interests in the blocks. Reflecting both the complexities of Polynesian tenure and the intricacies of Māori tribal history, cases could be almost impossible to unravel and could sometimes take weeks or even months to hear, and could then be followed by rehearings, petitions to Parliament or to the government, and reinvestigations.

DF, 2009); and Miguel A Centeno and Agustin E Ferraro (eds) State and Nation Making in Latin America and Spain: Republics of the Possible (Cambridge University Press, Cambridge, 2013). For an analysis of the effects of liberal state-building on indigenous communities in 19th century Spanish America, see Carmen Bernand Les Indiens face à la construction de l'État-nation: Mexique-Argentine 1810-1917 (Atlande, Paris, 2013).

8 Investigations of title were a core function of the Native Land Court, and derived originally from s 12 of the Native Lands Act 1862, and ss 21-29 of the Native Lands Act 1865. By the time of the Omahu case, the Court's powers to investigate titles derived from s 17 of the Native Land Court Act 1886. The current Māori Land Court still possesses a jurisdiction to investigate titles, but for all practical purposes this jurisdiction is now spent, there being no customary land left to investigate (with a few exceptions aside, such as some lakebeds, or lands accidentally left out of earlier surveys).

9 For these decisions, together with full commentaries, see Boast, above n 2, at 1168-1190 (original judgment at (1886) 2 Otorohanga MB at 55-70 [Rohe Potae]) and 1092-1101 (original judgment at (1886) 4 Taupo $\mathrm{MB}$ at 68 [Tauponuiatia]).

10 Native Lands Act 1865, s 12; Native Lands Act 1867, s 16; Native Land Amendment Act 1874, s 74; Native Land Court 1880, s 11; and Native Land Court Act 1886, s 9. The assessors were required to be Māori. On the assessors generally, see Boast, above n 2, at 135-140. The Assessor for the Omahu case of 1890 was BFJ Edwards.

11 The only types of case in which the Crown was regularly involved arose out of the Crown purchasing system, as that developed after the enactment of the Native Lands Acts. The Court often had to partition blocks between interests sold by owners to the government and those retained by "non-sellers", as they were styled. On the Crown purchasing system after 1865, see RP Boast Buying the Land, Selling the Land: Governments and Maori Land in the North Island 1865-1921 (Victoria University Press, Wellington, 2008). 
The Native Land Court was given jurisdiction in cases of succession at the very beginning of its existence. The Native Lands Act 1862 made no specific reference to succession, probably because it was assumed that the legal interests Crown-granted under the Act would simply be governed by the ordinary law relating to intestacies and wills. ${ }^{12}$ However, the Native Lands Act 1865, drafted by Francis Dart Fenton - who became the first Chief Judge of the Native Land Court - made elaborate provision for successions. The Preamble to the 1865 Act stated that one of the purposes of the Act was to provide for "the regulation of the descent" of lands investigated by the Court. ${ }^{13}$ Section 30 of the Act specifically bestowed on the Court jurisdiction in cases of successions. Section 30 stated:

Court may ascertain proper representatives of owner dying intestate: In any case any Native shall die or shall have died seized or entitled at law or in equity of or to any hereditaments and without having made a valid disposal of such hereditaments by will or settlement it shall be lawful for the Court upon the application of any person claiming to be interested in any such hereditaments to inquire into the matter and ascertain by such evidence as it may think fit who according to law as nearly as it can be reconciled with Native custom ought in the judgment of the Court to succeed to the hereditaments whereof or whereto such person may have died so seized or entitled as aforesaid or to any part thereof [emphases added].

There are a number of matters that merit comment arising from this provision, some obvious, others less so. First, and most importantly, the Court's jurisdiction in succession was confined to intestacies. The scheme of the Native Lands Acts was to convert customary titles into Crowngranted freeholds. So, logically, Crown grantees, who were, after all, legal owners of freehold estates, could devise them by will. This would require probate in the ordinary courts. The Native Lands Acts did not discourage Māori people from making wills - quite the reverse. Secondly, the Court's jurisdiction was confined to "hereditaments", meaning in this context the proprietary interests created by the Native Lands Act itself. The Court did not at first have jurisdiction over chattels, money and so forth left by a person dying intestate. Thirdly, the Court's jurisdiction over intestate hereditaments was to be exercised according to the ordinary law "as nearly as it can be reconciled with Native custom". That is, the ordinary law was the aspiration, but it was recognised that it needed to be qualified by Māori customary practice.

12 The 1862 Act provided that the Court or Courts set up under the Act had power to ascertain the title of tribes, communities and individuals; the Governor could then confirm the proceedings of the Court. The Court was to "sign and issue a Certificate of Title in favour of the Tribe Community or Individuals whose title shall have been ascertained" (Native Lands Act 1862, s 12). In the case of certificates issued to individuals, or fewer than 20 persons, a final certificate was to be made by the Governor which was to "have the same force and effect as if the same were a Grant from the Crown in fee simple" (s 15). In all cases, the Court's certificate "shall be conclusive as to the particulars and extent of the Land affected thereby" (s 14). For a full analysis see Boast, above n 2, at 61-96.

13 Native Lands Act 1865, preamble. 
The leading case on successions in the Native Land Court is the Papakura decision of 1867, relating to a block of land near Auckland. In this case Ihaka Takanini Te Tihi was the owner of the block under Crown grant, although exactly how the Crown grant had come about is uncertain. ${ }^{14} \mathrm{He}$ died intestate, and Ihaka's widow thereupon applied to the Native Land Court for an order vesting the block in their three children. This, however, was opposed by Heta Te Tihi, the deceased's brother, and others of the hapu. ${ }^{15}$ Their argument was essentially that Ihaka held the land as a trustee for the tribe and that Māori custom ought to prevail, and that the lands held by the deceased should now revert to customary ownership and pass to the customary owners. A witness named Te Hapimana said that he remembered the deceased, "Chief Isaac", and that he had three legitimate children: ${ }^{16}$

I belong to the [Aua?] tribe and reside at Orakei. He remembered the deceased Chief Isaac. He was married. Did not know when the marriage took place. He lived with his wife before marriage. Did not know when the marriage took place. They had children after the marriage. There are three alive. Their names are Te Wirihana, Erina, and Ihaka. These were born after wedlock. Is a relative of the deceased chief. Was not aware whether Isaac ${ }^{17}$ made a will or any settlement relative to the property in dispute. He made a verbal statement. He made a lease of the land. He did not say to whom it was leased. Objects to the land being given to the children of Isaac as there were many claimants, Isaac owned a piece and other natives owned pieces in the block. Knew nothing about the Grant but knew about the lease. Did not hear till lately about the Grant.

Heta Te Tihi confirmed that the land was leased, adding that he was one of those who received some of the rent. ${ }^{18}$ Later recalled to the stand, Heta Te Tihi stated that had Ihaka made a will, he would have left the land to his children on trust, but that portions would go to the collective group as well: ${ }^{19}$

Did not see the land surveyed or the surveyor. Had Isaac made a will he would not have left the land to the children, he would have left it in the hands of others on trust for them. (Were it his own case he would have given it to the children if grown up, but placed it in the hands of trustees if they were young.) The tribe would have their shares or pieces. It was right for Isaac to get the Crown Grant.

14 Those objecting to the land passing to the children said that they were not aware that the land had been Crown-granted. Heta Te Tihi said that he thought that Ihaka had died in December 1863 or at the beginning of 1864: (1867) 1 Auckland MB at 51 (Boast, above n 4, at 363). If correct, this must mean that Ihaka's grant could not have arisen under the Native Lands Acts but by some other means.

15 See (1867) 1 Auckland MB at 51 (Boast, above n 4, at 364).

16 (1867) 1 Auckland MB at 44-45 (Boast, above n 4, at 364).

17 That is, Ihaka.

18 (1867) 1 Auckland MB at 45-46 (Boast, above n 4, at 364).

19 (1867) 1 Auckland MB at 47-48 (Boast, above n 4, at 365). 
The significance of the point at issue can be readily seen. At stake was the very nature of an interest in Crown-granted Māori land. To allow any claim on behalf of the customary owners would in effect circumvent the whole purpose of the Native Lands Acts, which was to turn customary interests in Māori land into legal interests equivalent to freehold property rights. Chief Judge Fenton was in no doubt that this could not be allowed: ${ }^{20}$

It would be highly prejudicial to allow the tribal tenure to grow up and affect land that has once been closed with a lawful title, recognised and understood by the ordinary laws of the country.

Individualisation of title had to involve the introduction of the English law of succession. It might also have struck Fenton that it would be highly anomalous and inconsistent to, on the one hand, have a rule that in the event of a will being made then the land would pass under the terms of the will, but on the other, to allow Māori customary law to apply should a grantee die intestate.

Fenton was not, however, prepared to wholly allow ordinary English succession law to apply, which at that time was that property belonging to a person who had died intestate passed to the "heir at law". At common law, heirs were ranked under a number of rules which preferred the succession of males to females, and of the oldest son in preference to younger brothers (primogeniture). It is presumably these rules that Fenton had in mind - and which he deemed very unsuitable for Māori people. He did "not think the descent of the whole estate upon the heir-at-law could be reconciled with native ideas of justice or Maori custom". ${ }^{21}$ Fenton thus came up with a rule of his own devising: where a Māori grantee died intestate, the interests should pass to all children (whether male or female) equally. It is fair to say that he was attempting to create some kind of intermediate rule lying between English law and Māori customary law. The rule would apply, obviously, whether the grantee was the father or mother of the children; should both parents die intestate, and both parents be grantees, then the children would take equal interests from both, irrespective as to whether the children were living with their mother's or their father's relations. Parents could of course circumvent this outcome by making a will.

This rule swiftly became standard practice in the Native Land Court and was applied on thousands of occasions, to an extent which is impossible to quantify. The Court's minute books show there were many such cases at virtually every sitting of the Court and in all parts of the country. In most instances they were routine, and generated little controversy and little or no evidence in the Court records. But some cases relating to successions were very different. Some were matters of great public controversy. None was more so than the affair of Renata Kawepo's will

20 FD Fenton (ed) Important Judgments Delivered in the Compensation Court and Native Land Court, 18661879 (Henry Brett Printers, Auckland, 1879) at 20. The judgment is not actually in the Minute Book, as would be the usual practice. The collection published under Chief Judge Fenton's direction in 1879 contains a small sample of leading judgments of the Compensation Court and the Native Land Court.

21 Fenton, above n 20. On Fenton's edition of Court judgments see Boast, above n 2, at 227-229. 
and the Omahu block. To call this matter dramatic is an understatement. It was a tragedy in every way.

The Native Land Court later came to acquire a probate jurisdiction, with respect to wills made by Māori people (1894-1967), but at the time of the Omahu drama this still lay in the future. Thus while title to Omahu was a matter for the Native Land Court, probate of Renata Kawepo's will fell within the jurisdiction of the Supreme Court. The matter of jurisdiction came to be especially important with respect to Māori customary wills or dying declarations (ohāki), as will be seen. But the real matter at stake with the Omahu block was the actual scope of Renata Kawepo's interests under the will. Title to Omahu had never been defined, and it was still Māori customary land. If Renata had a large interest in Omahu, then that added significantly to the interests devised by his will. However the Supreme Court had no power to investigate titles to Māori customary land, or to fix the relative interests of owners. These were matters solely within the jurisdiction of the Native Land Court, as was clear from the relevant statutes and which the ordinary courts had themselves recognised. ${ }^{22}$

The law of succession as applied to Māori land interests, and Māori will-making in the 19th century more generally, deserve much more scholarly attention than either have received to date. Succession was a core component of the tenurial transformation brought about by the Native Lands Acts, but it has received a lot less attention from scholars than has the Court's primary investigation of title jurisdiction. How often Māori made wills in the 19th century is not known, but the frequency by which succession cases in the Native Land Court were struck out on proof of a will may indicate that Māori will-making was comparatively widespread. Nor is it known whether Māori wills were written in English or Māori, or the extent to which Māori obtained legal advice before making a will. In Latin America there is widespread scholarly interest in indigenous will-making, but research in New Zealand is yet to follow suit. ${ }^{23}$

22 The ordinary courts treated a certificate of title by the Native Land Court as conclusive: Piercy $v$ Petara (1884) 2 NZLR SC 306; Attorney-General v Tipae (1887) 6 NZLR 157 (CA). Nonetheless, cases involving various collateral problems relating to Māori land interests were commonplace in the ordinary courts including the Court of Appeal and on occasion even in the Privy Council - in the 19th century, and generated a vast amount of reported case law. For a survey of these cases, see Boast, above n 2, at 197-218. These cases were not for the most part concerned with common law native title, still less with the Treaty of Waitangi; they related rather to the nature and incidents of statutory Māori land titles under the Native Lands Acts.

23 Wills have been studied intensively by scholars of the "New Philology" school associated with James Lockhart and Stanford University. The "New Philologists" study "mundane" legal documents such as wills written in indigenous languages such as Nahuatl or Maya in order to chart shifts in language and social organisation. Prominent examples of this scholarship include Sarah Cline Colonial Culhuacan, 1580-1600: A Social History of an Aztec Town (University of New Mexico Press, Albuquerque, 1986); James Lockhart The Nahuas after the Conquest: A Social and Cultural History of the Indians of Central Mexico, Sixteenth Through Eighteenth Centuries (Stanford University Press, Stanford, 1992); and Matthew Restall The Maya World: Yucatec Culture and Society 1550-1850 (Stanford University Press, Stanford, 1997). On indigenous 


\section{THE LOQUUS IN QUO AND DRAMATIS PERSONAE}

Omahu was a large block of land (7,500 acres) in Hawke's Bay located between Napier and Hastings. By 1890, the date of its investigation of title, it was one of the few uninvestigated blocks of Māori land remaining in Hawke's Bay and was very valuable. By the time of the title investigation the principal groups resident on the block were Ngāti Hinemanu and Ngāti (or Ngāi) Te Upokoiri. There were two large villages on the block, at Runanga and Kawera, and part of it was intensively cultivated. These two descent groups were at odds, and were rival claimants to the block.

The block was a particularly troublesome one and lay at the heart of a bitter and intractable dispute within the Hawke's Bay Māori aristocracy. It was routinely referred to in the newspapers as the "famous" Omahu block - famous, that is, because of the dispute. ${ }^{24}$ The tensions derived, to some extent, from two competing wills of the great Hawke's Bay chief Renata Kawepo, although it is possible that matters were the other way around: the dispute over the will was a manufactured one and the real matter at stake was the bitter struggle over the land between Ngāti Hinemanu and Ngāti Te Upokoiri. Renata Kawepo, born around 1808, was a prominent rangatira of Ngāti Te Upokoiri and Ngāti Kahungunu. He was a committed Christian and as a young man had been one of the Māori teachers working with William Colenso, Church Missionary Society (CMS) missionary in Hawke's Bay. In the 1850s Renata was a prominent political opponent of Tareha, Te Moananui and Te Hāpuku, and other rival Hawke's Bay chiefs over land issues; in the 1860s he was sympathetic to the Māori King movement, hostile to Pai Mārire ("Hauhauism") and played an important role in the campaigns against Te Kooti. He was active in educational projects for Māori and died a senior and respected figure at Omahu in April 1888. At the time of his death Renata Kawepo was an important and powerful individual, prominent in local politics and business. He was also a very rich man: his estate was worth over $£ 100,000$. (By no means were all Māori people in colonial New Zealand poor and marginalised: some were very well-to-do and can be said to be part of the governing elite of the country.) About 6,000 people, many of them Pākehā - including the Native Minister, Edwin Mitchelson - attended Renata Kawepo's tangi in 1888, a testament to his prominence in provincial and national affairs. ${ }^{25}$ It was a military funeral: "Several hundred Volunteers took part, the funeral

wills and successions specifically, see Sarah Cline and Miguel Leon-Portilla (eds) The Testaments of Culhuacan (UCLA Latin America Center Publications, University of California, Los Angeles, 1984); Susan Kellogg and Matthew Restall (eds) Dead Giveaways: Indigenous Testaments of Colonial Mesoamerica and the Andes (University of Utah Press, Salt Lake City, 1998); and Caterina Pizzigoni Testaments of Toluca (Stanford University Press, Stanford, 2006). On the possible implications of this style of research for Pacific and New Zealand studies see RP Boast "Bringing the New Philology to Pacific History" (2011) 42 VUWLR 399.

24 "The Famous Omaha [sic] Block" Star (Christchurch, 14 February 1890) at 4.

25 On Renata Kawepo, see Patrick Parsons and Angela Ballara "Kawepo, Renata Tama-ki-Hikurangi" in Dictionary of New Zealand Biography (Allen \& Unwin and Department of Internal Affairs, Wellington, 1990) vol 1 at 218-219. 
being a military one, in recognition of Renata's loyal services during the Maori wars. ${ }^{26}$ Renata's principal wife predeceased him, but, as the Privy Council put it, "he was survived by two spouses of inferior rank, whose precise legal status has not been explained". ${ }^{27}$

The two contending parties, in what became an increasingly complex dispute pursued simultaneously in the ordinary courts and the Native Land Court, were Renata's grandniece Airini (Irene), and Renata's adopted son Wiremu Muhunga Broughton. Airini was married to George Prior Donnelly, who was Irish, and she is usually referred to in the sources as Airini Donnelly or Tonore. ${ }^{28}$ Airini was a true Māori aristocrat, the daughter of the chief Karauria and Haromi Te Ata, who was unofficially adopted by Renata Kawepo and brought up by him. In the years before the Omahu cases in the Native Land Court, however, Airini and Renata had become estranged, "chiefly on account of her marriage, but also on account of land disputes". ${ }^{29}$ Airini was involved in particular in a claim in the Native Land Court to the huge Owhaoko block near Taihape, a claim which was in opposition to Renata's own claim to these lands. She is a controversial figure to this day, but was certainly a person of great ability. Airini was well-steeped in Māori traditional history and was able to hold her own in any important political meeting. When the Native Minister, John Ballance, visited Hawke's Bay in 1886 in order to explain the objectives of his Native Land Administration Bill, Airini stood to address the Minister herself at a meeting at Waiputu near Hastings, a meeting attended by Māori chiefly leaders from all over the country. ${ }^{30}$ She was also something of a professional litigant and was involved in numerous cases in the Native Land Court and the ordinary courts, including several in the Court of Appeal - two of which ended in the Privy Council. ${ }^{31}$ She feuded with many people, including the no less formidable Gertrude Meinertzhagen,

26 "The Funeral of a Chief" Star (Christchurch, 21 April 1888) at 3.

27 Donnelly v Broughton, above n 1, at 436 per Lord Watson.

28 See generally SW Grant "Donnelly, Airini" Dictionary of New Zealand Biography (Allen \& Unwin and Department of Internal Affairs, Wellington, 1993) vol 2 at 121. George Prior Donnelly was born in County Tipperary and was of Irish gentry background. George came to New Zealand in 1863 and moved to Hawke's Bay in 1867 where he became the manager of a sheep station and soon acquired his own land. He married Airini in 1877, and by the turn of the century he and Airini owned a number of sheep stations and other properties around Hawke's Bay which afforded George sufficient income to breed and train racehorses. The couple were presented at the Court of St James, along with their daughter Maud, in 1900. See Boast, above n 11 , at 262-263.

29 Broughton v Donnelly (1888) 7 NZLR 288 (CA) at 288 (headnote).

30 See Notes of Native Meeting at Hastings [1886] AJHR G2 at 11.

31 In the Native Land Court, Airini was involved in numerous cases involving many large and valuable blocks, mostly in the Hawke's Bay and Taihape regions. Examples include the cases relating to Omahu, Kaiwaka, Owhaoko, Porangahau, Mangaohane and Awarua. Some of these large inquiries generated litigation in the ordinary courts. The two Privy Council cases are Donnelly v Broughton, above $\mathrm{n} 1$ (Airini was the plaintiff) and Te Teira Te Paea v Te Roera Tareha [1902] AC 56 (here Airini was one of the defendants, the plaintiffs being the Māori customary owners of the Kaiwaka block north of Napier). Other cases she was involved in were the Court of Appeal decisions in Donnelly v Meinertzhagen (1908) 10 GLR 384 (CA) and Winiata Te 
lessee of the Waimarama block in south Hawke's Bay. ${ }^{32}$ Airini was closely connected with the powerful Dunedin-based lawyer and politician Sir Robert Stout, a key personality on the left wing of the Liberal Party, who was both a friend and her legal adviser. The Donnellys eventually came to own a number of valuable properties around Hawke's Bay and were prominent members of Hawke's Bay gentry society - an upper-crust social grouping which included a number of well-to-do Māori people including Airini herself and her cousin Kurupo Tareha.

Wiremu Broughton, born in Wanganui, was also adopted by Renata Te Kawepo and brought up by him. After Renata Kawepo's death in 1888 , he was regarded by many in the Māori community as the chief of Ngāti Te Upokoiri by adoption. ${ }^{33}$ Broughton was active in farming, local and national politics, and training racehorses (also a passion of the Donnellys): no less than Airini, he was undoubtedly a member of the Hawke's Bay governing elite. Broughton was a very prominent and popular figure in Māori and provincial affairs, and seems to have been well-liked by many people in the province. He was active in educational matters and was a long-standing member of the Omahu School Committee. ${ }^{34}$ His tangi in 1908 was a major event, and was attended by James Carroll, the Native Minister in the Liberal Government, and many other prominent Māori and Pākehā people.

\section{RENATA KAWEPO'S WILL IN THE SUPREME COURT AND THE COURT OF APPEAL 1888}

Having no issue of his own, Renata left his extensive land interests to Broughton by his will. This will, dated 12 January 1887 (in the words of Richmond J), "had been prepared by a solicitor, bears the full and usual signature of the testator, and is attested by a Justice of the Peace, the clerk of the Resident Magistrate's Court at Hastings, a licensed native interpreter, and two other witnesses". ${ }^{35}$ The will made careful provision for the protection of Renata Kawepo's people by requiring that the executor shall "well, carefully, and faithfully see to the welfare and well-being of my hapus and people, and reserve such of my lands for their use and occupation, and make such

Wharo v Airini Tonore (1895) 14 NZLR 209 (CA); and the Supreme Court decision in $R v$ Airini Tonore (1902) 22 NZLR 220 (SC).

32 The legal and political battle over Waimarama between Airini Donnelly and Gertrude Meinertzhagen also attracted a great deal of public attention and involved some leading political personalities, including the Prime Minister at the time, Richard Seddon (he was another friend and connection of the Donnellys). On the Waimarama affair, see SW Grant Waimarama (Dunmore Press, Palmerston North, 1997). See also Donnelly $v$ Meinertzhagen, above n 31 .

33 "The Late Wi Broughton" Hastings Standard (Hastings, 17 March 1908) at 3 ("The natives of Omahu contend that Wi Broughton by being adopted by the late chief Renata Kawepo, and by being brought up and educated by him, by right of adoption on the death of Renata becoming chief of the Nga te Upokoire tribe, his remains should have been brought to Omahu for the usual rites accorded to the dead.") Broughton died on 10 March 1908.

34 At 2.

35 Broughton v Donnelly above n 29, at 305-306 per Richmond J. 
provision therefor as to him shall see fit". ${ }^{36}$ This direction was in fact pivotal to the whole dispute, which was to some degree one between a customary group and a particular family. ${ }^{37}$ The will also made provision for the payment of annuities to Renata Kawepo's second and third wives. Whether Airini intended to do so, had she been successful over the will, is unknown.

This will was challenged by Airini, who produced a second will supposedly in her favour. This resulted in the litigation over the will which ended finally in London. The Native Land Court's investigation of title into Omahu became inextricably entangled with the litigation over the will in the ordinary courts, and a number of other blocks of land, such as the nearby Pukehamoamoa block and Owhaoko near Taihape, also became dragged into the dispute. Essentially, the parties contending in the Native Land Court were the same parties contending over the will in the ordinary courts. The will passed Renata Kawepo's land interests, which were partly defined, and partly undefined. The undefined interests lay in the Omahu block: "undefined", as already explained, because Omahu still had never been investigated. Renata also had various defined interests in a number of large inland blocks of land in what was at that time known as the "inland Patea", essentially the area around Taihape. These latter blocks included the Owhaoko, Mangaohane and Oruamatua-Kaimanawa blocks, all of which had complex procedural and tenurial histories in their own right. ${ }^{38}$

Airini Donnelly's stance was a complex one. She was claiming in the ordinary courts that she, and not Broughton, was the heir under the will. At the same time, however, she was seeking to defeat the Ngāti Te Upokoiri claim to Omahu in the Native Land Court - Ngāti Te Upokoiri being Renata Kawepo's primary tribal affiliation. There must be a connection between these two seemingly contradictory positions, and it seems likely that they were not in fact contradictory at all. If Airini and her supporters were successful in the Native Land Court, this would mean that Omahu was not actually Renata Kawepo's to bestow, thus largely nullifying the effect of a successful outcome for Broughton in the dispute over the will. This seems to have been the principal outcome in the end. Broughton won his case in the Privy Council, but significant interests at Omahu went to

36 As cited in the Privy Council judgment in Donnelly $v$ Broughton, above n 1, at 437.

37 However it is necessary to be cautious before leaping to the conclusion that the dispute was simply between Ngāti Te Upokoiri on the one hand, and Airini and her immediate kin group on the other. Airini also had her supporters and wider kin groups. However, while the will to Broughton made express provision for Ngāti Te Upokoiri, the one-line will for which Airini was seeking probate suggested nothing of the kind. Had Airini been wholly successful in the Land Court and in the ordinary courts that would have been a major blow for Ngāti Te Upokoiri, but this is not what happened.

38 See the Owhaoko relative interests decision (1885) 11 Napier MB at 48-54 (Boast, above n 2, at 10791089); the Oruamatua Kaimanawa relative interests decision (1885) 11 Napier MB at 54-56 (Boast, above $n$ 2, at 1089-1091); and the Owhaoko Reinvestigation decision (1887) 13 Napier MB at 97-114 (Boast, above $\mathrm{n} 2$, at 1217-1230) (this case was a contest essentially between Renata Kawepo and Airini Donnelly over this 163,000 -acre block). 
Airini's group in the Native Land Court proceedings, thus significantly denting the value of Renata Kawepo's estate and thus the value of the land interests devised to Broughton.

In opposing the grant of probate to Broughton in the Supreme Court on behalf of herself and her brothers and sisters, Airini did not challenge the validity of the first will but relied on the supposed second will as a revocation of the first. While the first will was a complex legal document, the second was a brief note in Māori in the following terms: "The persons for my will [wira] are Airini and her younger brothers and sisters and their children." 39 Airini said that two days before his death, Renata asked Airini to write out the new will at his dictation while his two wives were lying asleep in the same room. Airini then brought in two additional family members who witnessed the document. Renata was too weak to execute the document, and Airini, so she said, made a mark at Renata's direction. At the foot of the will was the signature "Renata + Kawepo", with a cross or a mark of some kind between the two words, plus the two signatures of the witnesses. The two wives, supposedly, remained asleep throughout. Broughton, technically the plaintiff in the Supreme Court, argued, as Prendergast CJ put it, "that the alleged execution was a forgery, or at any rate that the evidence of the alleged execution is such that the Court ought not to act upon the evidence and find in favor of the due execution of the will". 40

Airini was successful at first instance. On 6 August 1888, Prendergast CJ, who heard the case without a jury, issued his decision, finding that Renata was of sound and disposing mind when he made the second will (which operated as a revocation of the first). Prendergast's rather elaborate and lengthy decision was principally focused on the evidence relating to Renata's intentions, as could be inferred from the surrounding circumstances and the evidence of other witnesses, in particular Archdeacon Samuel Williams of the Church of England. ${ }^{41}$ Williams gave evidence that he had seen Renata on his deathbed shortly after the new will had allegedly been made. Williams' evidence is summarised as follows by the Court of Appeal: ${ }^{42}$

At 4 o'clock, Mr. Williams being again in the room, Renata awoke out of a sound sleep. Broughton, Mrs Donnelly, and some others were present. "Renata," says Mr. Williams, "looked up to me and said, 'You are asking me about my will.' I asked him what he meant. I had forgotten that I had spoken in the morning. He repeated, 'You are asking me about my will?' I then said, 'Speak on, as I am listening to anything you have to say to me.' He then pointed to Airini (Mrs. Donnelly) who was sitting at the foot of

39 Broughton v Donnelly, above n 29, at 289. In the Privy Council the appellants were listed as "Mrs. Airini Donnelly, who is of pure Maori blood, her infant daughter Maud Donnelly, her two Maori brothers and their infant children, and her two sisters": Donnelly v Broughton, above n 1, at 436.

40 Broughton v Donnelly, above n 29, at 291 per Prendergast CJ.

41 The "Archdeacon Williams" referred to in the decision must be Samuel Williams, son of the prominent CMS missionary Henry Williams. Samuel Williams lived in Hawke's Bay, and leased and managed the Te Aute estate near Hastings, and was active in diocesan affairs.

42 Broughton v Donnelly, above n 29, at 309. 
his bed, and said either 'Ki a ia' [to her], or 'Kei a ia' [she has it]. I am not sure which he said. He continued to say, 'the old one to be entirely destroyed, or set aside,' moving his hand as casting off from him. 'The Pakeha husband to have nothing to do with it."' The Maori words used, as given by Mr.

Williams, were, "Te mea o mua me kore rawa atu. Ko te tana Pakeha me kore rawa atu."

Williams, connected to a prominent missionary family, and a person of some importance in Hawke's Bay affairs as the lessee of the Te Aute estate (attached to the prestigious Māori boys' school of the same name), was regarded as a pivotal witness by Prendergast. Williams' evidence confirmed Airini's narrative, notwithstanding the fact that there were some troubling aspects with regard to her version of events, and the Supreme Court found that the second will was valid and effective, and not obtained by undue influence.

Airini's victory, however, was shortlived, and three months later Prendergast's decision was reversed by the Court of Appeal. The Court of Appeal's judgment, given by Richmond J, was released on 13 November 1888. Richmond J thought some aspects of Airini's behaviour were very hard to explain, in particular the fact that Broughton was never told about the new will: ${ }^{43}$

The making of the alleged new will was kept secret from Broughton and the other persons interested under the will of 1887 until after Renata's death, although several fit opportunities occurred for procuring its recognition by Renata in the presence of the persons principally interested in contesting it.

The Court of Appeal thought it completely implausible that Renata would ever want to leave everything he had to Airini and her siblings. She had married George P Donnelly without Renata's approval, and it was well-known that Renata disliked Donnelly intensely. Airini had fought Renata in the Native Land Court over the Owhaoko block near Taihape. ${ }^{44}$ On the other hand, there had been a reconciliation between Airini and Renata shortly before his death. Nonetheless: ${ }^{45}$

... after all due allowance, it seems improbable, having regard to their previous relations during many years, that Renata should have intended to make her the mistress after his death of his whole tribe and property.

Rather than focusing on the testimony of Archdeacon Williams, the Court of Appeal placed primary emphasis on the evidence of James Carroll, a prominent Māori politician who became Native Minister in 1899. Carroll was of the view that Renata was not talking about his whole estate, but rather about the Owhaoko block (where Airini, as it happens, had opposed him with her own

43 At 306-307.

44 Owhaoko was a large block of about 163,000 acres in the Taihape region, first investigated in 1875 . Relative interests were defined in 1885 and the block was reinvestigated following an inquiry by a parliamentary committee in 1886. It was reinvestigated in 1887 and the reinvestigation was reheard in 1888 . See Boast, above n 2, at 1079-1088.

45 Broughton v Donnelly, above n 29, at 307. 
claim in the Native Land Court). Renata was very anxious about Owhaoko, and was insistent that the claim to it by Tūwharetoa (a powerful Māori tribal grouping located around Taupo) - a claim regarded as spurious by Renata - had to be opposed at all costs. ${ }^{46}$ Carroll interpreted Renata's actions on his deathbed to mean that he intended that Airini should take over his interests in Owhaoko while leaving the bulk of his estate to Broughton, as per his earlier will. Carroll was regarded by the Court of Appeal as an impartial witness with no stake in the outcome, and concluded Carroll's version of events was much more plausible in the circumstances. For these and other reasons, Prendergast's decision was reversed, probate was granted to Broughton and costs were awarded against Airini on the highest scale. By way of a parting shot, the Court of Appeal stressed that any suggestion that Māori wills should be treated differently from other wills could not be entertained: ${ }^{47}$

We have only to add that in our opinion the rules which govern Courts of Probate should by no means be relaxed in the case of alleged testamentary papers executed by Maoris on their death beds. It may even be questioned whether the law as it stands does not offer dangerous temptations to fraud which it would be wise to guard against by legislation.

The dispute over the will and the investigations of title in the Native Land Court were simultaneous processes. Both were extremely politicised and attracted considerable public attention. After Wiremu Broughton's success in the Court of Appeal in 1888, he returned home to Hastings in triumph, and to a torchlight procession through the town on 29 November 1888. The scene was described in the Daily Telegraph (Napier): ${ }^{48}$

Last night, shortly after seven o'clock, the streets began to get crowded, while by eight o'clock it was difficult to make one's way through the principal streets, which presented a very animated appearance indeed. Everyone seemed to wend their way in the direction of the White road crossing, where $\mathrm{Mr}$ Broughton and party were met by a most enthusiastic crowd, who lustily cheered as that gentleman stepped into the coach, to which was attached four greys. A long procession was then formed; nearly all the cabs in the town followed, while a number of natives, waving torches in the air as they proceeded along the street, seemed to enjoy it immensely.

Clearly this was no ordinary succession dispute. Broughton made a speech to his cheering Māori and Pākehā supporters, thanking them for their support. With regard to his victory in the Court of Appeal: ${ }^{49}$

46 At 315. Tūwharetoa are the iwi of the Taupo district. They had claimed interests in Owhaoko, as had Airini and Renata and their respective supporters.

47 At 319

48 "Mr. Wi. Broughton." Daily Telegraph (Napier, 30 November 1888) at 2.

49 At 2. 
... he did not think of himself, but always of the tribe [that is, Ngati Te Upokoiri] that had been left by that noble chief, and he thanked them, not only on his own behalf, but out of respect to that great chief, who was now dead - Renata Kawepo; because, if Mrs Donnelly's will had been upheld, no doubt the public generally, and the natives more particularly, would have declared that Renata Kawepo was a dishonourable man to his own people".

We are told that during the speech "the speaker was cheered at intervals, and at it conclusion the Masonic Hotel was rushed, and many of the crowd refreshed themselves". Following his success in the Court of Appeal, Broughton then took possession of Omahu as part of Renata Kawepo's patrimony which had not passed to him by means of the will. "When Broughton took possession Airini raised up natives on her side, and the squabbling has been going on ever since." 50

The public support in Hastings for Broughton reveals that the conflict was not at all merely one between two individuals. Much larger interests were at stake. Renata's will had, as explained above, been careful to provide for the well-being and support of Ngāti Te Upokoiri and other hapu. Airini had a certain amount of support from others beyond her immediate kin-group, although how much support is uncertain. Victory for Airini over the will meant victory for herself and her siblings and cousins; victory for Broughton meant victory not just for Broughton but also for Ngāti Te Upokoiri. The contestation in the Land Court was somewhat different. Ngāti Te Upokoiri were pitted against the hapu or hapus at Omahu to which Airini belonged, but which was a larger class of people than those who stood to benefit from the second will. Victory for Airini on both fronts, however, would have seen a substantial number of Ngāti Te Upokoiri people driven out of Omahu, where a substantial number of them were living.

\section{TURANGA KARAURIA AND WAATARA WI'S TRIAL FOR MURDER}

Airini Donnelly, well able to afford expensive litigation, then lodged an appeal to the Privy Council over the will. While it was pending in London, attention turned to the investigation of Omahu by the Native Land Court. By the time of the investigation of title to Omahu the standoff between Airini Donnelly's and Wiremu Broughton's parties had become entrenched. In June 1889 matters came to a head when Karauria, Airini's brother, and a well-respected young man, was shot dead at Omahu by Wiremu Broughton's uncle, Waatara Wi, who had the "reputation of being a remarkably quiet and well-behaved man". 51 This incident was known to everyone in the province and was widely covered in the local press. When reporting in 1890 on the Omahu decision, the Poverty Bay Herald noted that "judgment was given by the Native Lands Court at Hastings on the ownership of the famous Omahu block, over which there have been so many disturbances and even

50 "Cause of the Trouble: Broughton-Donnelly Litigation" Auckland Star (Auckland, 14 June 1889) at 3.

51 "The Omahu Murder" New Zealand Herald (Auckland, 1 November 1889) at 5. 
bloodshed". ${ }^{52}$ The Herald went on to note that "it was for alleged trespass on this block that Turanga Karauria, brother of Airini Donnelly, was shot by Waatara Wi, one of Broughton's natives, who claimed ownership under the will of Renata Kawepo". ${ }^{53}$ Karauria was shot in the course of an armed struggle, which led to an inquest at Napier and eventually to Waatara's imprisonment for 10 years' penal servitude. ${ }^{54}$

The shooting was described in detail in the Hawke's Bay Herald on 15 June 1889. The narrative given in the newspaper is a window into the political tensions within the Māori community over Omahu: 55

\begin{abstract}
At about 6 o'clock yesterday morning a well-known young Maori named Turanga Karauria, brother to Mrs Donnelly, was shot at Omahu by a native named Waatara Wi. The latter, a tall and powerfully-built man, apparently from 35 to 40 years of age, is $\mathrm{Mr}$ W. Broughton's uncle. The affair, which appears certain to result fatally judging from the condition of the wounded man, grew out of the long-continued dispute with which the public are, unfortunately, too well acquainted. On the day preceding the affray Waatara Wi was ploughing in a paddock near the church at Omahu, and Turanga and a party of Donnelly-ites were ploughing in another paddock. Both, it is said, were ploughing not so much for purposes of cultivation, as for asserting tribal rights in the manner dear to the Maori mind.
\end{abstract}

There are some similarities perhaps with the ploughing of confiscated land in Taranaki by men from Parihaka in 1881 as a protest against the government. Ploughing land is an assertion of ownership. The ploughing of the land by Karauria was a provocative act, but no less so than Broughton's decision to take possession following his victory in the Court of Appeal. Whether Airini Donnelly knew of her brother's plans is unknown, but it is interesting that local newspapers refer to Karauria and his friends as "the Donnelly natives". To continue the narrative: ${ }^{56}$

So far as can be ascertained, when Waatara had ceased work on the evening of the $13^{\text {th }}$ instant, the Donnelly natives determined to get up very early next morning and plough that portion of the land upon which Waatara Wi had been engaged. At 3 o'clock, or perhaps a trifle earlier, the Donnelly natives, in charge of Turanga Karauria, got up and fed their horses and harnessed up four ploughing teams. After having breakfast the men and the teams started for the paddock where it was intended to plough, and entry was obtained to the ground by breaking down a portion of the fence. While the ploughing was in progress Waatara Wi went up to Turanga, as the leader of the party, and after a formal salute in Maori

52 The Omahu Land Dispute: Judgment of the Land Court" Poverty Bay Herald (Gisborne, 14 February 1890) at 2 .

53 At 2 .

54 On the inquest, see "The Omahu Tragedy" Hawke's Bay Herald (Napier, 26 June 1889) at 3.

55 "The Omahu Land Dispute: Serious Shooting Affray" Hawke's Bay Herald (Napier, 15 June 1889) at 3.

56 At 3 . 
fashion demanded that the ploughing should be stopped. Turanga refused to stop the ploughing. Some little altercation took place, which was suddenly brought to an abrupt conclusion by Waatara Wi levelling a revolver at Turanga. The latter immediately turned to run behind his team of horses, but after he had taken a stride or two Waatara, who was on horseback, fired, the bullet hitting Turanga a little to the right of the spine, and in the neighbourhood of the short ribs. He did not fall, but ran away and got over a short fence, making for the road which led to Mrs Donnelly's house ... Turanga then made a spring at his assailant, who fired again, but missed.

Others became involved: $: 57$

A struggle took place between the men, Turanga seeking seeking to throw his assailant to the ground and to wrest from him the revolver. He succeeded in doing this as some other natives came up - a youth named Taka and two women, one of them Turanga's wife. Upon getting possession of the revolver Turanga commenced to strike Waatara upon the head with it, but the women took the weapon away and themselves proceeded to batter Waatara Wi, who received a number of nasty scalp wounds, and was nearly rendered unconscious, the women at this time behaving as if they intended to kill Waatara. But when it became known how seriously Turanga was injured, and that he was shot in two places, and was bleeding freely from his wounds, the shock seemed to restore the party to something like reason ... and in a short time a messenger was despatched to town [Napier] to inform the police of the affair and to bring back a doctor to Omahu.

Waatara, "in a sorry plight", was arrested and placed in a prison cell at Napier. Turanga Karauria died of his injuries and Waatara was later charged with murder. At the coroner's inquest the jury brought in a verdict of manslaughter on the basis of provocation, but the coroner refused to accept the verdict and redirected the jury on the law. They did not, however, change their minds, no doubt being well aware of the fraught situation that lay behind the shooting. ${ }^{58} \mathrm{Wi}$ was detained in the jail at Napier. The Wellington Grand Jury brought in a true bill for murder against Waitara Wi on 29 November and he was tried for murder in the Supreme Court at Wellington in November 1889.59 Defence counsel raised a plea of justification "on the disturbances which had arisen in the once peaceful village after the death of Renata Kawepo, and the effect the estrangements had on the nature of the Maori". ${ }^{60}$ It was also argued that not all of the shots were fired by Waatara and that the fatal shot was fired during the scuffle. The jury brought in a verdict of manslaughter, and Prendergast CJ sentenced Waatara to 10 years' penal servitude.

57 At 3 .

58 "The Omahu Tragedy" Hawke's Bay Herald (Napier, 6 July 1889) at 3.

59 "The Broughton-Donnelly Case" Wanganui Chronicle (Wanganui, 29 October 1889) at 2. This reports also that Mrs Donnelly and Wiremu Broughton were also charged at the same time with forcible entry.

60 "The Omahu Murder Case" Wanganui Herald (Wanganui, 2 November 1899) at 4. 
The Hawke's Bay Herald thought that the lesson was clear. It was the failure to have the title investigated and clarified in the Native Land Court which was the principal reason for the tragic killing of Karauria: ${ }^{61}$

There is a lesson for the Government in the tragedy at Omahu by which a fine young native, intelligent, popular, and well educated, has lost his life. That lesson is not to delay the investigation of native titles over which inter-tribal disputes rage. It has been known for years that bad blood existed over the Omahu block, and twice Courts have been appointed to investigate the title. Twice the Courts have adjourned

without doing so. Why, we know not - the fact is there.

\section{INVESTIGATION OF TITLE TO THE OMAHU BLOCK, 1890}

The Native Land Court investigation, acting under the shadow of the events described above, which were well-known to all present, commenced in July 1889, just a few weeks after Karauria's death and while Waatara was in custody awaiting trial. At the time of the case, according to newspaper sources, Broughton was "in possession" of Omahu. ${ }^{62}$ The case began with disputation over who the claimants were (that is, whether Donnelly and Broughton had the status of claimants or counter-claimants, which was procedurally important), whose survey map should be relied on and an argument about the independence of the Māori Assessor. ${ }^{63}$ The case was a mammoth affair, and lasted for nearly six months, with extensive cross-examination on both sides. The evidence given in the Native Land Court happens to be very well-recorded, and survives in two separate sets of records: the official Court minute books (vols 18 and 19 of the Napier Minute Books) and also in the minutes kept by the Court's Māori assessor, BJF Edwards. Airini claimed, according to the judgment, "the whole block under the Rangikamangungu, Hawea, Tuhotaoriki, and Pakapaka, under four gifts, except the southwest part, which she claims under the ancestor Pukeake, grandson of Mahuika". ${ }^{64}$ The claims were made under the headings of "bravery", "mana" and "occupation".

The Native Land Court (Judges O'Brien and von Stürmer, BFJ Edwards, Assessor) released its judgment on 13 February 1890. The judgment is a long and complex text. The Court was not at all happy about the case, and regretted that the parties had not been able to reach some kind of a settlement out of Court. "Few cases", the Court remarked, "have been heard in the Native Lands Court more intricate than this": 65

61 "The Omahu Dispute" Hawke's Bay Herald (Napier, 17 June 1889) at 2.

62 "The Broughton-Donnelly Dispute" Wanganui Herald (Wanganui, 15 June 1889) at 2.

63 "Native Land Court" Hawke's Bay Herald (Napier, 10 July 1889) at 3.

64 (1890) 20 Napier MB at 132 (Boast, above n 4, at 498).

(1890) 20 Napier MB at 131 (Boast, above n 4, at 498). Often judgments in the Native Land Court are written out in longhand in the minute books, but in this case the judgment is printed: it is an extract from a newspaper cut into several columns and pasted directly into the minutes at folios 131-134. There is no handwritten text of the judgment in the minutes, as would still be usual at this time. The newspaper is not 
First, it presents aspects not common; some of the old landmarks are totally changed, rivers taking new courses, old cultivations in some instances swept away, names of hapus changed and indiscriminately used, as one or the other suits; individuals taking different sides during various fights alleged to have influence on the title to this land, some of these individuals now taking fresh sides in this case; suppression of facts by some who apparently did not think it their interest to mention them, and allegations by others which have been unsupported or contradicted; and an unnecessary division of parties, thereby unduly protracting what was otherwise a case not easy of solution. All these circumstances have tended to increase our labour in disentangling this case, and arriving at a satisfactory conclusion.

The bulk of the judgment consists of a long analysis of the contentions put to the Court by the opposing sides on extremely complicated traditional history, including the more recent circumstances by which Ngāti Te Upokoiri came to live on the block. The Court, asked to investigate and partition the block, concluded that the exercise it was called on to perform, and which it did indeed perform, was actually impossible, if not pointless: ${ }^{66}$

In closing our judgment we are unable to define the interests of the parties whom we thus place together. We would willingly accord them separate portions had we seen our way, but they have been so mixed up that we are unable to do so. If the parties would agree to any arrangement we would most willingly give effect to it in our judgment, meantime we can only say that ... we think that Airini Tonore ${ }^{67}$ has, as the representative of Te Rangikamangungu ${ }^{68}$ and Hawea, ${ }^{69}$ with her party, the largest interest in this portion of the block which she calls Oingo, and part of Otupaopao, subject however to the remarks which we have made as to the part now in occupation of [Ngāti Upokoiri], extending from the mouth of the Ohiwia stream to the church and generally known as old Omahu.

The Court has often been accused of riding roughshod over Māori wishes and aspirations. Yet, as can be seen, the Court here would willingly have given effect to any arrangement that the parties might have come to amongst themselves, if that had only been possible.

The judgment in the Omahu case partitioned the block but in a way that was significantly in favour of the group led by Airini Donnelly. According to the Bush Advocate, a South Hawke's Bay newspaper, and thus well-informed about the competing interests at stake, the judgment meant that

identified in the minutes but is in fact "Judgment in the Omahu Case" Hawke's Bay Herald (Napier, 14 February 1890) at 2 . The fact that the judgment was printed verbatim in the local newspaper is testimony in itself to the level of public interest in the affair.

66 (1890) 20 Napier MB at 134 (Boast, above n 4, at 505).

67 That is, Donnelly.

68 Name of an ancestor.

69 Also the name of an ancestor. 
"those who base their claim under Renata's [Renata Kawepo's] mana have been signally defeated". The net effect of the judgment was that the valuable flat land in the block had been split in two: ${ }^{70}$

The Court roughly divided this flat portion into two unequal parts, the line of division, which is irregular, going through the middle of Renata's pah. The south-east half - that nearest to Napier - has been awarded to Mrs Donnelly and her co-claimants. It was on this part of the land that Turanga [Karauria] was shot by Waatara Wi for alleged trespass, though the judgment of the Court decides that he was on the territory of his people.

The Poverty Bay Herald, a newspaper which always paid close attention to the Native Land Court, reported that the judgment was "almost in favour of [Airini] Donnelly and her people", and that only "some insignificant portions have been awarded to Renata's people on the ground of special gifts by Airini's ancestors". ${ }^{71}$ This was an exaggeration. However, although on its face the decision seems to be a compromise, dividing the block between the two contending groups, local press comment clearly gives the impression that Airini Donnelly and the group she led had won a significant victory in the Native Land Court. Perhaps this was because the part of the block she and supporters were allocated was the most valuable and best-developed part of the block and that closest to Napier.

The tensions between the two contending groups were now such that the Court's judgment nearly resulted in violent resistance by some members of Wiremu Broughton's group, who - in an echo of the dispute that had resulted in Karauria's death - started ploughing land near to the place where he had been shot. This threatened to cause another detonation. The chairman of the local native committee, Mohi Te Atahikoia, and the local resident magistrate, Captain Preece, both had to intervene in order to minimise the risk of another serious confrontation. The aftermath of the case was described in detail in the Hawke's Bay Herald on 1 August (under the heading of "More Trouble at Omahu"): ${ }^{72}$

When the Native Land Court at Hastings gave judgment in the Omahu subdivision case certain natives who were dissatisfied applied for a rehearing. It was then arranged between the parties that no ploughing was to take place on a certain portion of the block near the cemetery, and on the same side of the road to the paddock in which Karauria was shot. Other parts were laid out in which the several parties were to be allowed to plough. We learn that certain natives in opposition to Mrs Donnelly's family interests have been ploughing on the reserved ground. This aroused a good deal of feeling, and, fearing that trouble might ensue, some of Mrs Donnelly's people interviewed Captain Preece, R.M., on the matter. He went out to Omahu on Monday, and, after investigating matters, told the offending natives that the ploughing must cease. They promised him that they would desist, and left off ploughing then, but on the following

70 "The Omahu Land Case" Bush Advocate (Dannevirke, 15 February 1890) at 2.

71 "The Omahu Land Dispute" Poverty Bay Herald (Gisborne, 14 February 1890) at 2.

72 "More Trouble at Omahu" Hawke's Bay Herald (Napier, 1 August 1890) at 3. 
morning they were at work again. Iraia Karauria, on behalf of the old natives and parties interested, again interviewed Captain Preece, and warned him that if the ploughing were not stopped serious results might follow. Mohi Te [Atahikoia], ${ }^{73}$ the chairman of the native committee, went to Omahu yesterday, and tried to stop the ploughmen, but they refused, and Mohi then came to town and saw Captain Preece, who at once communicated with $\mathrm{Mr} \mathrm{W}$. Broughton, and in the afternoon Mr Broughton wired to say that he had given orders for the ploughing to be stopped at once. It is to be hoped this is the end of the affair. If the ploughing is resumed the authorities should take steps to promptly stop it. It was through the want of prompt action that one of the brightest young natives in the North Island was murdered, and another native is now serving a long term of penal servitude. Some of the younger natives hanker after vengeance, and though their elders have hitherto restrained them a little additional provocation may prove too much, and cause serious trouble. After the shooting of Karauria all the firearms in the pa were supposed to have been given up to Captain Preece. If that were done other guns have since been purchased, for there are firearms and plenty of ammunition there now.

Fortunately there were no more shootings.

\section{OMAHU ROUND II: KAWERA BLOCK AND THE OHĀKI ISSUE}

Following the decision on investigation of title relating to Omahu, the Court began to deal with ancillary matters such as partitions (subdivisions) and lists of owners. Kawera was a subdivision of the Omahu block. Some months after the main decision, a new issue arose over the effect of Renata Kawepo's will. Counsel for Broughton, Mr Cornford - who had been Waatara's defence counsel at the murder trial in Wellington - claimed in the Kawera partition case that Renata Kawepo's first will was an "ohāki", or testamentary declaration, made according to Māori customary law and thus cognisable in the Native Land Court. At the time of this hearing the appeal relating to the Renata Kawepo's will was pending in the Privy Council in London.

Why would Cornford take this approach? The point must be that if the will leaving all interests to Broughton had the status of an ohāki then this immediately circumvented the legal issue of the competing wills. An ohāki was a matter of Māori custom, and only the Māori Land Court had jurisdiction over Māori custom. The argument must have been based on the assumption that the ohāki would include everything that belonged to Renata Kawepo by Māori custom, including his interests in Omahu itself - the very issue that was in debate in the Native Land Court.

73 Mohi Te Atahikoia was a prominent Hawke's Bay chief who fought as an ally of the government against Te Kooti during the New Zealand wars, who later became chairman of the Hawke's Bay Native Committee and a leader of the Te Kotahitanga parliamentary movement. He also became involved in the long legal battle to have Te Whanganui-a-Orotū (Napier Inner Harbour) restored to Māori ownership. Mohi Te Atahikoia was a notable scholar and the author of a number of historical works written in the Māori language. See Angela Ballara "Te Atahikoia, Mohi?-1928, Ngāti Kahungunu leader, politician, historian" in Dictionary of New Zealand Biography, above n 28, at 514-515. 
As the Privy Council had not yet ruled on the matter, Cornford sought to have the proceedings relating to partition and allocation of owners relating to Kawera adjourned pending the outcome of the decision of the Privy Council; this was opposed by counsel representing Airini Donnelly and her group, the latter being the principal beneficiaries of the order on investigation of title made in February. According to the Hawke's Bay Herald for 24 April 1890: ${ }^{74}$

During the hearing of the Omahu case, lately decided by the Native Land Court, Mr Cornford, on behalf of certain persons claiming under the will of the late Renata Kawepo, asked the Court to reserve the decision as to the devolution of Renata's ${ }^{75}$ interest until judgment should have been given in the Privy Council in the will case, and that in the meantime the order for Kawera, one of the sub-divisions of the Omahu block, should be held over.

The respective arguments of counsel are set out fully in the minutes: ${ }^{76}$

Mr Cornford for Mr Broughton.

Mr Carlile for Mrs Donnelly.

Latter addresses the Court saying that the European probate is a matter of indifference as this Court has to decide who is entitled according to native custom. At the date of the will the land had not passed through the Court, and at the date of the death the land was held under native tenure. The only therefore to inquire is who are the natives now living who are entitled to the land according to native custom. The power of the Court is under the $19^{\text {th }}$ section of the "Native Land Court Act 1886". It is clear from the acts of the legislature by which this court is governed that no power exists for recognising a deceased native in any part of the proof of title to lands. The law as to succession is very strict. In the Act of '86 Native land is defined, and the $56^{\text {th }}$ section of the Act of ' 73 made provision for a native dying during adjudication. It may be said that there is a power of gift by native custom - but not for European probate - and native custom must guide. A will can't be construed as a gift after death. A case may be stated for the Supreme Court. If people are entitled under a probate they are not entitled according to native custom, and court must disallow. This is a new question and opens an infinite [] as natives may have made similar wills in general terms. If [ ] past questions will follow and one monstrous result would be the award to Europeans of possible interests, would the Court allow that? This case is on all fours with such a one and the result is a reductio ad adsurdum. It is repugnant to native custom and is unsupported by statutory law that a native can devise in general terms the interest that he claims in native lands.

Cornford's response was as follows: ${ }^{77}$

74 "The Omahu Block" Hawke's Bay Herald (Napier, 24 April 1890) at 4.

75 Referring to Renata Kawepo.

76 (1890) 20 Napier MB at 349-350 (Boast, above $\mathrm{n} 4$, at 511).

77 (1890) 20 Napier MB at 350 (Boast, above n 4, at 512). 
The decision of the Privy Council will decide this matter. We don't claim under European probate - we say it is a gift - "ohaki" - under native custom. An owner of native land may dispose of it in any manner. We say it makes no difference whether the disposition is made in the presence of respectable Europeans or before natives. This is purely a case of Maori custom on which the Court will proceed according to that custom. If our will is upset by the Privy Council our ohaki must go. This is a question of Maori law as is evidenced by a document in Maori and attested original.

The Court adjourned the matter for a number of days in order to consider the point. It found that there was insufficient evidence to establish the existence of an ohāki. Its judgment on this point is of some interest.

The Court took the position that an ohāki, being a Māori customary disposition of property, can be enforced by the Native Land Court as a recognised form of customary title to land. It found also that the Native Land Court had exclusive jurisdiction to determine whether any particular disposition should be treated as an ohāki or not. If it did have that status any decision the Privy Council might make was irrelevant. The "[Native Land] Court alone is the judge of such a document, and no decision of the Privy Council could affect it as an ohaki if it were truly one". ${ }^{78}$ This followed because the Native Land Court had exclusive jurisdiction over matters of Māori customary law. ${ }^{79}$ To that extent Cornford was correct. In this case, however, Renata Kawepo's will (that is, the first will), whatever other status it might have, was not in the Court's view an ohāki according to Māori custom and therefore was not enforceable by the Native Land Court. An ohāki, observed the Court, "is the last dying declaration of a chief to his family and people". ${ }^{80}$ It is "the verbal disposal of his property or lands amongst his family and kindred, and it is only made when in extremis". The will here was obviously not an ohāki: ${ }^{81}$

The will of Renata Kawepo was made in an office in a European township, before European witnesses, when he was in good health, and can in our opinion be looked upon only in the light of an ordinary will. Mr Cornford's admission that the reversal of the will by the Privy Council will destroy its effect as an ohaki satisfies us that he himself does not view it in the light of an ohaki or native disposition of property, but, as we do, looks upon it as an ordinary will.

78 (1890) 20 Napier MB at 353 (Boast, above n 4, at 513).

79 In this instance the Privy Council appeal was an appeal from the ordinary courts. At this time appeals from the Native Land Court were by way of full rehearing only, but in 1894 the Native Appellate Court (today the Māori Appellate Court) was established by s 79 of the Native Land Court Act 1894. It was held by the Privy Council in Re The Will of Wi Matua (deceased) [1908] AC 448 that there was a right of appeal from the Native Appellate Court directly to the Privy Council.

80 (1890) 20 Napier MB at 353 (Boast, above n 4, at 513).

81 (1890) 20 Napier MB at 353 (Boast, above n 4, at 513). 
The ohāki argument therefore failed. Broughton's legal team did not take the point any further. In 1895 the law was altered. Section 33 of the Native Land Laws Amendment Act 1895 provided that "[n]o interest in land or personal estate shall pass by an unwritten will or ohaki".

\section{THE PRIVY COUNCIL DECISION IN DONNELLY V BROUGHTON}

The Privy Council decision in Donnelly v Broughton was released on 4 July $1891 .{ }^{82}$ It was the first Māori case that the Privy Council ever heard, and it is interesting that it was not a case involving the Crown but was an inter-Māori contest. The judgment of the Judicial Committee was given by Lord Watson. He analysed the factual circumstances of the making of the will very carefully, and generally agreed with the interpretation of the Court of Appeal.

The Privy Council's starting point was that Airini was not only the principal beneficiary of the putative second will but was the person who had prepared the document and executor. Anyone in this position, according to the English law of probate, was "himself an interested person, [and] his conduct must be watched as that of an interested person". ${ }^{83}$ Moreover, this strict standard can be increased if certain circumstances apply, in particular "unbounded confidence in the drawer of the will, extreme debility in the testator, [and] clandestinity". ${ }^{84}$ The Privy Council agreed with the Court of Appeal that there was no reason to apply a different rule in the case of Māori testators: ${ }^{85}$

... their Lordships entirely concur in the opinion expressed by Richmond, J., to the effect that "the rules which govern Courts of Probate should by no means be relaxed in the case of alleged testamentary papers executed by Maoris on their deathbeds".

Lord Watson thought it a "singular thing" that Renata had believed that Airini, according to her testimony, had already been directed to prepare a will for him. It was no less "singular" that he had asked Airini to do that "instead of one or other of the agents whom he was in the habit of employing for business purposes, of whom there was no scarcity in Omahu at that time". ${ }^{86}$ These circumstances suggested some doubts "as to the mental condition of Renata, induced by physical weakness"; Renata "certainly was not in a good state for executing a settlement without the deliberate aid of some unprejudiced person". ${ }^{87}$ There were some other odd things about the circumstances which the Privy Council noticed. Why was it that Airini happened to be carrying around materials for writing

82 Donnelly v Broughton, above $\mathrm{n} 1$.

83 At 442, citing Paske v Ollat (1815) 161 ER 1158.

84 At 442, quoting Paske v Ollat, above n 83, at 1159.

85 At 443, citing Richmond J in Broughton v Donnelly, above n 29.

86 At 443.

87 At 443 
out a will on short notice? Why did she write out the document herself, when others who were present, including the doctor, could have done so? But it was the clandestine aspect of the circumstances which was most notable, and most striking: ${ }^{88}$

Last of all, the transaction, according to Mrs. Donnelly's own narrative of it, was characterized by what Sir John Nicholl terms "clandestinity." 89 Assuming the will to have been made as Mrs. Donnelly alleges, the fact that no outsider was present at its execution did not afford a legitimate reason for keeping its existence secret. If the witnesses on both sides are to be believed, Renata was not a man to be driven from his settled purpose; and if the fact that he had made a new will had been divulged, it is more than probable that there would have been no room now for any question either as to his having executed a will or as to his understanding of its terms.

The Privy Council judgment also analyses the testimony of Archdeacon Williams but concluded that it only went to show that either Renata did not understand the contents of the new will, or "that the will in question is of domestic manufacture for the purpose of defeating the respondent's rights".90 The Privy Council agreed with the Court of Appeal that probate of the second will should be refused. The appellants were ordered to pay the costs of the appeal.

The Privy Council decision was widely reported in New Zealand newspapers. The result was cabled to New Zealand on 6 July 1891, but persons interested in the case had to wait for the full text of the decision until it was brought to New Zealand on the SS Kaikoura, arriving in October. The judgment was then immediately printed in full in the Hawke's Bay Herald on 8 October, taking up several closely printed columns of the newspaper. ${ }^{91}$ No doubt it was widely read in Napier and Hastings. Everyone in Hawke's Bay would have had the opportunity to see the Privy Council's conclusion that the will could have been of "domestic manufacture", no doubt confirming what many people will have believed. Many reports drew attention to the costs of the litigation. The Evening Post advised its readers: "The costs from the beginning to the end of the litigation will amount to several thousands of pounds". 92 The litigation was not quite over, and there were further proceedings in the Court of Appeal in November 1891 where Broughton asked the Court of Appeal to increase the costs award against Airini. ${ }^{93}$

88 At 444 .

89 Paske v Ollat, above n 83, at 1159.

90 At 446

91 "The Renata Will Case: Full Judgment of the Privy Council" Hawke's Bay Herald (Napier, 8 October 1891) at 4 .

92 "The Renata Kawepo Will Case: Final Judgment for Broughton" Evening Post (Wellington, 6 July 1891) at 2.

93 "Law Costs in a Disputed Will Case" New Zealand Herald (Auckland, 5 November 1891) at 5. 


\section{ROUND III, REHEARING, 1892}

However the story of the investigation of title to Omahu had yet another round to go. The Omahu block was completely reheard in 1892. The rehearing, in effect, allowed the decision of the Privy Council relating to the will to be relitigated, because everything now depended on the definition of customary interests at Omahu. Following the very lengthy hearings, ${ }^{94}$ two separate joint judgments were delivered by Chief Judge Seth-Smith and Judge Scannell. The first, given on 7 April, dealt with the substantive arguments raised at the rehearing; the second set out the principal subdivisions of the block. ${ }^{95}$ There was also a third supplementary judgment in response to an application by William Rees, counsel for Ngāti Te Upokoiri (Wiremu Broughton's group) that the Native Land Court state a case for the opinion of the Supreme Court.

The rehearing began at Hastings on 25 February 1892. Nine claims had been lodged with the Court: (1) from Paora Kaiwhata and others; (2) from Airini Tonore and others; (3) from Wiramina Ngahuka and others; (4) from Wiremu Broughton and others; (5) from Henare Tomoana and others; as well as four late claims from Maraea Piri, Matenga Pekapeka and others. The principal parties were, as before, Airini Tonore's (or Donnelly's) group, which had a powerful legal team which included Sir Robert Stout, later to be Chief Justice, and Wiremu Broughton's claim on behalf of Ngāti Te Upokoiri. They also had a substantial legal team which included William L Rees, fresh from his stint as chairman of the Rees-Carroll Commission of 1891 and a lawyer with a long and varied experience in Māori land issues. Rees, who had the difficult task of showing that the previous decision was wrong in some way, took a very combative approach to the case (as was typical for him), taking every possible point. In the end, not getting a sufficiently favourable judgment for his clients, he told the Court that he intended to have its decision reviewed by the Supreme Court.

The case had again aroused considerable local interest and was regularly covered in the Hawke's Bay Herald, the Poverty Bay Herald and other papers. When the Chief Judge of the Land Court gave his decision "[t]he Court was crowded" and "almost all the Napier Bar was present". 96 The Hawke's Bay Herald summarised the effect of the 7 April decision for its readers as follows: ${ }^{97}$

We publish on the fourth page the judgment of the Native Land Court in the Omahu re hearing case. Briefly described, it excludes some of the smaller claimants who were found to be entitled under the original judgment, and practically declares the whole block to be owned by the contending Broughton and Donnelly factions. The dividing lines set up by the Court at the original hearing are, however, abolished. Roughly, the Broughton natives are declared to have a preponderating influence in one part,

94 The lengthy evidence is recorded in (1892) 25 and 26 Napier MB; and (1892) Judge Scannell's MB.

The principal judgment is at (1892) 26 Napier MB at 7-8 (Boast, above $\mathrm{n} 4$, at 692-702).

96 "Omahu Judgment" Daily Telegraph (Napier, 7 April 1892) at 3.

97 "Omahu" Hawke's Bay Herald (Napier, 8 April 1892) at 2 (emphasis in original). 
and Mrs Donnelly's natives a preponderating interest in another part, based on occupation. The Court will on Monday proceed to define the boundaries between the two hapus more definitely, but it will not individualise any titles. As we read the judgment, the final number will be largely influenced by the number of natives on each side. Afterwards the natives found to be entitled can proceed to individualise their titles if they so please, but not at the present sitting of the Court.

The second judgment, given later in the month, defined the interests of the competing parties in detail. The Hawke's Bay Herald reported: "The general impression ... is that the judgment leaves things very much as they were before the appeal, so far as the principal parties are concerned". 98 Finally on 29 April William Rees, counsel for Wiremu Broughton, invited the Court to state a case to the Supreme Court. The Court issued an additional judgment on 30 April declining to do so, whereupon Rees announced his intention to apply to the Supreme Court for a writ of prohibition. Whether he actually did so I have not been able to discover.

The rehearing Court was no less dissatisfied with the various competing claims than the Court of first instance. The judgment complained of "numerous contradictions and discrepancies" and went on to observe that: 99

... the greater part of the story that has been laid before us is either the result of ingenious invention, or of the unconscious change which necessarily takes place in the handing on of tradition from mouth to mouth, especially where the remembrance of the real facts has been hazy.

All the parties were part of Ngāti Kahungunu in a general sense, and some of the evidence revolved around the circumstances and effects of the conquest of the region by Taraia I and his grandson Taraia II centuries before, intractable material which the Court seems to have regarded as bewildering and irrelevant. The core issue, however, was that of the interests of Renata Kawepo's Ngāti Te Upokoiri at Omahu in the early-19th century. If I understand the evidence and the judgment correctly, Ngāti Te Upokoiri were driven out of Omahu as the result of their defeat in a battle at a place called Rotoatara. ${ }^{100}$ In the year 1840 Ngāti Te Upokoiri were no longer living at Omahu. Nevertheless, at some point after that date - I am not certain when, as this is not stated in the judgment - Ngāti Te Upokoiri were invited to return to Omahu by the prominent chief Te Moananui. The Court took the position that when Ngāti Te Upokoiri returned, their ancient rights at Omahu revived. The Court was not convinced that there were any real boundary lines between Ngāti Te Upokoiri (Renata Kawepo and Wiremu Broughton's people) and those descending from the ancestors Rangikamaungu (or Te Rangikamangungu) and Hawea (Airini's people). Nevertheless the Court was required to allocate the block between the two groups and did so, allocating Ngāti Te

98 "The Omahu Re-hearing" Hawke's Bay Herald (Napier, 29 April 1892) at 3.

99 (1892) 26 Napier MB at 7 (Boast, above n 4, at 696).

100 (1892) 26 Napier MB at 7 (Boast, above n 4, at 698). 
Upokoiri roughly the southern and western part of the block and the groups led by Airini the rest of the block. The other smaller claims to the block were mostly dismissed.

In making this allocation the Court had to deal with the so-called "1840 rule", by which claims to land in the Native Land Court were, supposedly, freeze-framed as at $1840 .{ }^{101}$ But by this time the "rule", if it was ever such, was much attenuated. A strict application of the rule could have meant that Ngāti Te Upokoiri got nothing, as presumably Airini Donnelly and her legal team argued, but the Court baulked from such a harsh outcome (which, incidentally, could have robbed Broughton and his supporters of much of the benefit of the Privy Council decision over the will given in the previous year, although the Court does not mention this). The Native Land Court's remarks on the "1840 rule" are very interesting: ${ }^{102}$

If it were the duty of the Court to imagine itself sitting in the year 1840, immediately after the introduction of the British Government into the colony, we should have come to the conclusion that Ngatiteupokoiri were not owners of this land. But we also think that if we were placed under the necessity we should also be obliged to find that no natives had any beneficial interests in this land at that time, and if the strict interpretation of the so called rule of 1840 were insisted upon the experience of the present members of the Court leads us to believe that a very large area of the land in the North Island would be found to be without a native owner.

The main decision of 7 April seems to have made little significant substantive alteration to the decision on investigation of title made two years earlier. The Court was required to divide the block between the parties using the powers conferred upon it by the Native Land Court Act 1886. The parties wished to have the block divided, and the Court saw this as jurisdiction it was required to exercise, but in fact the Court did not believe that there actually was a clear boundary between the competing parties, thus concurring with the 1890 decision of the Native Land Court. There was in fact "no ancestral line that can guide us"; thus in exercising its jurisdiction, the best that the Court could do was to make such divisions "as seem to us most in accordance with the interests of justice and conducive to the good order of the community generally".

The costly and ruinous dispute had no beneficial outcomes. Omahu was partitioned between Airini's descent group and Broughton's Ngāti Te Upokoiri. Wiremu Broughton committed suicide in 1908. His suicide "was a surprise to most of his very large circle of friends and acquaintances, but

101 The "1840 rule", so-called, is a rule of practice in the Native Land Court by which customary entitlements are fixed at the date of the acquisition of British sovereignty in 1840. The starting-point for the rule is the decision of the Compensation Court, presided over by FD Fenton (first Chief Judge of the Native Land Court), in the Oakura case [1866] AJHR A13 (see Boast, above n 2, at 281-311). By the time of the Omahu case the effect of the "rule", if it was ever such, had become significantly diluted. For a full discussion of the 1840 rule, see Boast, above $n$ 4, at 126-137.

102 (1892) 26 Napier MB 7 (Boast, above n 4, at 698). 
Dr Pomare informed us yesterday that he had been suffering from melancholia of late". ${ }^{103}$ Airini died in June 1909 at the age of 55. She was survived by George and their daughter Maud Airini Tiakitai Perry, who had been presented at the Court of St James in 1900. Maud eventually sold the extensive properties in Hawke's Bay left to her by her mother and married again, to a Mr La Morte. She too became involved in litigation (over gift duty relating to the Kaiwaka block). ${ }^{104}$ George Prior Donnelly died in 1917. Most of his estate, including the "testator's stud thoroughbred horse business and all horses and appurtenances thereof" went to Maud and her children. ${ }^{105}$

\section{SOME REFLECTIONS}

I have sought here to contextualise the Donnelly $v$ Broughton affair, and to integrate it with the parallel story of the Omahu blocks in the Native Land Court, but it has to be admitted that much remains unclear. The mystery at the heart of the story is what Renata Kawepo's intention with regard to his estate actually was. Airini's story is full of implausibilities, as the Court of Appeal and the Privy Council could both see. Airini was certainly ambitious and could be unscrupulous, and invested much effort in litigation in the ordinary courts and the Native Land Court, but was she actually capable of forging a will and fabricating evidence? I am uncertain about that, which leaves open the possibility that she was genuinely mistaken as to Renata's intentions.

The more serious analytical difficulty, in my view, is that of integrating the twin narratives of the dispute over the will and the battle in the Native Land Court over Omahu. One objective of this article was to write a more contextualised understanding of the whole dispute, but it has to be admitted that the precise interconnections are not wholly clear. Why was it that Wiremu Broughton received such huge public support at Hastings? Was it because he was such a popular and engaging figure - as he obviously must have been - or was it because the battle over the will and Ngāti Te Upokoiri's rights at Omahu had become interlinked? As will be apparent, the latter seems very likely, especially taking into account the directions in the will to protect Renata Kawepo's Ngāti Te Upokoiri people. However the struggle was not simply one between Ngāti Te Upokoiri and Airini Donnelly and her immediate family, because Airini too had her friends and supporters at Omahu.

What is certainly clear is that there was a connection between the will and the Omahu cases in the Land Court, and that must be because, as already indicated, the value of Renata Kawepo's estate turned in part on the outcome of the contestation in the Court. Airini may have lost in the Privy Council, but if she and her descent group won control of Omahu as customary owners, then there would be no interest under the will with respect to Omahu that Broughton could inherit (although Renata had large interests in many other blocks). The converse equally applied. Thus the Land

103 "Wi Broughton's Suicide: Echoes of an Old Feud" Manawatu Times (Palmerston North, 12 March 1908) at 8.

104 "Perry v Commissioner: Judgment Reserved" Hastings Standard (Hastings, 3 May 1913) at 6.

105 "Late Mr G. P. Donnelly: Provisions of Will" Star (Christchurch, 4 September 1917) at 4. 
Court cases and the cases in the ordinary courts rebounded on each other. The net outcome, however, was roughly a draw in the Native Land Court, but a draw which leaned somewhat more to Airini's side, and a complete victory for Wiremu Broughton in the Privy Council. What the latter must have meant, although I admit I am only surmising here, is that Broughton would have benefited from the Omahu finding in the sense that he belonged to Ngāti Te Upokoiri. However, he would also have benefited from being the devisee of Renata Kawepo, who was Ngāti Te Upokoiri's great chief and who as such would have had large interests in the Omahu block according to Māori custom. This would in turn have become legal interests capable of passing by will, following a determination by the Native Land Court. However since Airini and her supporters did reasonably well in the Native Land Court as well, this would have cut into the value of the estate passed by the will to a significant extent.

What is interesting about this story, notwithstanding these uncertainties? The novelist LP Hartley once famously observed in the opening lines of his novel The Go-Between (1953) that "the past is a foreign country: they do things differently there". The Omahu story may be said to be an example of that. One component of the foreignness of the past is that our forebears can be intensely interested in matters that do not seem to be especially interesting and important to us, something which can tell us as much about ourselves as it does about history. Looking back from the present, we may seek to find in 19th century Hawke's Bay a struggle between Māori and the Crown over the Treaty of Waitangi and native title, and expect to see evidence of a struggle between Māori and Pākehā over land and resources. The Omahu case and the Donnelly-Broughton will affair is not about any of these issues. It is instead an intense personal and political drama within the governing landed class of Hawke's Bay, a class which is in fact partly Māori. We might expect to see communities that were separate from each other and divided along ethnic, cultural and linguistic lines, but the Omahu affair does not point to that either.

One aspect of the Omahu story that stands out is the intense contemporary interest in the complex twists and turns of the affair. The detailed press coverage of the various cases, of the tragic death of Karauria, and the widespread concerns about further violence in the wake of the first Omahu decision of the Native Land Court, speak for themselves. One can think, too, of Wiremu Broughton's return home from the Court of Appeal to a hero's welcome by the people of Hastings. What is especially interesting is that this intense interest was not confined to the Māori community. It is evident that by 1890 there is in fact a fairly integrated community - Māori and Pākehā - that together feels that the difficult problems posed by the Omahu affair are shared in, and are somehow important to, the community as a whole.

A second component that is very striking is that the dispute over Omahu, which it would be very easy to interpret as a battle about "land rights" was in fact a political struggle within the Māori aristocracy of the province. It might be said to be chiefly politics in a new guise, that of courts and tribunals, but which could also spill over into armed confrontations and violence. It became very public, and connected to local and national political alignments. There has been very little research 
on the Māori elite in 19th century New Zealand, but - to revert to a point made earlier - it is a complete misunderstanding of 19th century New Zealand to assume that Māori were all poor and oppressed. That certainly cannot be said of Renata Kawepo, Airini Donnelly or Wiremu Broughton. Perhaps this is how the twin battles over the will should be seen: as a continuation of chiefly politics in new legal contexts, albeit - and this too seems worthy of note - a Māori political struggle which absorbed the attention of the Pākehā population. There has been a great deal of research on indigenous elites in 19th century Latin America, for example in Peru, Guatemala and Mexico, and perhaps some of the insights gained from this research could be profitably applied to the study of New Zealand history. ${ }^{106}$ Elites and the governing class are no less interesting than the poor and downtrodden, and no less worthy of study. ${ }^{107}$ Moreover it is clear that the governing elite, or class, in Hawke's Bay, was partly Māori, as of course is true of the governing class of New Zealand today. There is no need to buy into the entirety of Marxist history to see this phenomenon, both historically and in terms of the politics of the present day, as full of interest.

A third general conclusion is that cases in the Native Land Court need to be placed in their full historical context before their importance and their effects can be fully understood. It would be quite possible to read the evidence and the judgments in the Omahu case without learning anything about the dispute over the will and Karauria's violent death, and to simply see the case as a reasonably neutral investigation into customary interests. But this is not the reality of what happened. The wider context created powerful incentives on the part of both sides to strain their interpretations of customary interests and traditional history to the utmost. One is left in a state of real doubt as to how much reliance can actually be placed on the voluminous evidence on these matters contained in the Court records relating to Omahu. How safely can this material be relied on as a window into traditional Māori history? A degree of caution and doubt is surely called for. It is important to emphasise this, given the extent to which evidence given before the Native Land Court is relied on by ethnohistorians to reconstruct the history of "tribal landscapes". Caution is especially necessary

106 See for example David T Garret Shadows of Empire: The Indian Nobility of Colonial Cusco, 1750-1825 (Cambridge University Press, Cambridge, 2005); Greg Grandin The Blood of Guatemala: A History of Race and Nation (Duke University Press, Durham, 2000); and Matthew Restall The Maya World: Yucatec Culture and Society, 1550-1850 (Stanford University Press, Stanford, 1997).

107 Some prominent examples of the scholarly study of elites are Lawrence Stone The Crisis of the Aristocracy, 1558-1641 (Oxford University Press, Oxford, 1967); Lawrence Stone and Jeanne CF Stone An Open Elite?: England 1540-1880 (Oxford University Press, Oxford, 1984); David Cannadine The Decline and Fall of the British Aristocracy (Picador, London, 1990); and Jane Ohlmeyer Making Ireland English: The Irish Aristocracy in the Seventeenth Century (Yale University Press, New Haven, 2012). New Zealand historians seem to shy away from the study of elites, perhaps being under the impression that New Zealand has none (if so, a hilariously inaccurate perception), or that elites are uninteresting (which is not the case, as I hope this article has demonstrated). There have been few historical studies of elites in New Zealand, and none at all of Māori elites. The only full-length historical study of elites in New Zealand that I am aware of is Stevan Eldred-Grigg A Southern Gentry: New Zealanders who inherited the Earth (Reed, Wellington, 1980). This book focuses on the South Island, and Canterbury in particular. 
in the case of fraught and politicised cases such as Omahu in which the stakes were very high and which were at the centre of public controversies.

Lastly, the intertwined story of Renata Kawepo's will and the investigation of the Omahu blocks underscores the importance of taking the effects of the law of succession into account in understanding the full consequences of the Native Lands Acts and the Native Land Court in New Zealand legal history. Tensions exploded not so much in the Native Land Court case, but with the contestation over Renata Kawepo's will. It is hard to penetrate beneath the drama of the contest in order to see the wider structural changes that are at work with regard to the law of succession, which in any case requires full analysis based on a solid sample of case studies. But it is certainly likely that the new world of wills and probate law was a key part of the transformation brought about by the Native Lands Acts. 